S. Parnovsky, Dr. Phys. and Math. Sci., Prof.

Taras Shevchenko National University of Kyiv, Kyiv

\title{
ESTIMATION OF THE COMBINATION OF SOME COSMOLOGICAL PARAMETERS \\ FROM LARGE-SCALE MOTION OF RFGC GALAXIES
}

A constrain on the combination of cosmological parameters $\Omega_{m}$ and $\sigma_{8}$ is obtained from the peculiar motion of RFGC galaxies. We find the estimation $\left(\Omega_{m} / 0.3\right)^{0.35} \sigma_{8}=0.87 \pm 0.05$.

Key words: large-scale motion of galaxies, cosmological parameters.

УДК 524.8

E. Fedorova, Ph. D. Taras Shevchenko National University of Kyiv, Kyiv

\section{X-RAY PROPERTIES OF DISTANT RADIO-LOUD QUASARS FROM THE XMM-NEWTON AND SWIFT/XRT DATA}

The X-ray data of XMM-Newton and SwiftXXR observations of the sample of radio-loud quasars with the redshifts $z>1$ from the cross-correlation of PKS radio catalog and Veron-Veron AGN catalog are processed and analyzed. The model the reflected and absorbed power-law spectrum with an exponential cut-off at high energies was applied to fit the main part of the spectra of these quasars in the energy range 0.3-10 кеB, except only gravitational lens system PKS1830-211 to which the broken power-law was used. The mean values of the parameters over the set are: photon index $\Gamma=1.59 \pm 0.04$, high-energy cut-off $E_{C}=77$ keV, reflection parameter $R=3.2$ and column density of the absorbing material $N_{H}=4.2 * 10^{21} \mathrm{~cm}^{-2}$. All the objects of the set, except PKS2000-330, demonstrate the exponential cut-off below $100 \mathrm{keV}$ in the spectrum, as it is prescribed to the RL AGNs within the spin-paradigm.

Key words: AGN, quasars, X-ray observations

Introduction. XMM-Newton public archive contains the observational data about 14 radio-loud quasars from PKS and Veron-Veron catalogs cross-correlation performed by Laurent-Mühleisen et al. [18]. Eight of them are published already $[5,12,16,21,23,27]$. The major part of these objects were observed earlier by the other cosmic X-rays missions: ASCA (PKS 0537-286[22, 25], PKS 2000-330 and PKS 0237-23 [22], PKS 2126-158 [22, 25], PKS 2149-306 [22, 24, 25] and RX J1028.6-0844 [22, 25]), ROSAT (PKS 0537-286[3], PKS 1830-211 [4, 5], PKS 2000-330 and PKS 2126-158 [10], PKS 2351-154 and RX J1028.6-0844 [28]), Chandra (PKS 2149-306 [11] and PKS 1830-211 [6]), INTEGRAL (PKS $1830-211$ [6], PKS 2149-306 [1]) and BeppoSAX (PKS 2126-158 [9]). These objects had been also analyzed with XMM-Newton (PKS 0537-286[21, 23], PMN0525-3343 [21], PKS 2126-158 [16, 21], PKS 2149-306 [1, 16, 21], RX J1028.6-0844 [21, 27]), PKS 1830-211 and PKS 1406-076 [12], and 4C06.41 [21]); and Swift (PKS 2149-306 [1, 15], PKS0537-286 [2], PKS 2126-158 [15], PKS1830-211 [8]), but it should be noticed that the Swift/XRT datasets used here for all teh objects except PKS 1830-211 are bigger that those used before. Also, there is some interest in the analysis of the RL quasars as a sample to reveal their average properties, both individual and average. For this purpose the XMM-Newton/EPIC and Swift/XRT data from the public HEASARC archive had been treated here. XMM-Newton Observation IDs, date of observations, total source counts and count rates in the extraction regions can be found in Table 1.

Table 1. XMM-Newton observation LOGs of the quasars sample

\begin{tabular}{|c|c|c|c|c|c|c|c|c|c|c|c|}
\hline $\begin{array}{l}\text { Object } \\
\text { name }\end{array}$ & Dataset ID & Obs. date & \multicolumn{3}{|c|}{ Exposure time, ks } & \multicolumn{3}{|c|}{ Count rate (cts) } & \multicolumn{3}{|c|}{ Total counts } \\
\hline & & & MOS1 & MOS2 & PN & MOS1 & MOS2 & PN & MOS1 & MOS2 & PN \\
\hline Q0952+179 & 0112850101 & 2001-05-10 & 32.0 & 32.0 & 29.5 & 0,078 & 0,081 & 0,249 & 2558 & 2670 & 14948 \\
\hline PKS0537-286 & $\begin{array}{l}0114090101 \\
0206350101\end{array}$ & $\begin{array}{l}2000-03-19 \\
2005-03-20\end{array}$ & $\begin{array}{l}42.5 \\
80\end{array}$ & $\begin{array}{l}42.5 \\
80\end{array}$ & $\begin{array}{l}45.4 \\
80\end{array}$ & $\begin{array}{l}0,256 \\
0.287\end{array}$ & $\begin{array}{l}0,256 \\
0.30\end{array}$ & $\begin{array}{l}0,796 \\
1.77\end{array}$ & $\begin{array}{l}10245 \\
22999\end{array}$ & $\begin{array}{l}15348 \\
23983\end{array}$ & $\begin{array}{l}65239 \\
141944\end{array}$ \\
\hline PKS1406-076 & $\begin{array}{l}0151590101 \\
0151590201\end{array}$ & $\begin{array}{l}2003-07-05 \\
2003-08-10\end{array}$ & $\begin{array}{l}23 \\
14\end{array}$ & $\begin{array}{l}23 \\
13\end{array}$ & $\begin{array}{l}20 \\
12\end{array}$ & $\begin{array}{l}0.059 \\
0.084\end{array}$ & $\begin{array}{l}0.063 \\
0.095\end{array}$ & $\begin{array}{l}0.099 \\
0.136\end{array}$ & $\begin{array}{l}1352 \\
1170\end{array}$ & $\begin{array}{l}1458 \\
1270\end{array}$ & $\begin{array}{l}1985 \\
1580\end{array}$ \\
\hline PKS1830-211 & $\begin{array}{l}0204580201 \\
0204580401 \\
0204580301\end{array}$ & $\begin{array}{l}2004-03-10 \\
2004-04-05 \\
2004-03-24\end{array}$ & $\begin{array}{l}30.0 \\
30.1 \\
31.0\end{array}$ & $\begin{array}{l}30.0 \\
30.1 \\
31.0\end{array}$ & $\begin{array}{l}29.9 \\
30.0 \\
30.0 \\
\end{array}$ & $\begin{array}{l}0,629 \\
0,627 \\
0,581\end{array}$ & $\begin{array}{l}0,62 \\
0,622 \\
0,572\end{array}$ & $\begin{array}{l}1,337 \\
1,723 \\
1,459\end{array}$ & $\begin{array}{l}19485 \\
20053 \\
18576\end{array}$ & $\begin{array}{l}19226 \\
19895 \\
18313\end{array}$ & $\begin{array}{l}78860 \\
105088 \\
88982\end{array}$ \\
\hline PKS2126-158 & 0103060101 & $2001-05-01$ & 22 & 22 & 18 & 0.989 & 1.004 & 5.456 & 21100 & 22189 & 98204 \\
\hline PKS2149-306 & 0103060401 & 2001-05-01 & 24.0 & 24.0 & 21.0 & 0,594 & 0,634 & 2,121 & 14837 & 15851 & 93305 \\
\hline $\begin{array}{l}\text { PMN0525- } \\
3343\end{array}$ & $\begin{array}{l}0149501201 \\
0149500601 \\
0050150101 \\
0149501001 \\
0149500701 \\
0149500901 \\
0149500801 \\
0050150301\end{array}$ & $\begin{array}{l}2003-08-08 \\
2003-04-06 \\
2001-02-11 \\
2003-03-25 \\
2003-02-24 \\
2003-03-16 \\
2003-03-06 \\
2001-09-15\end{array}$ & $\begin{array}{l}12.0 \\
11 \\
13 \\
11 \\
11 \\
11 \\
13 \\
28\end{array}$ & $\begin{array}{l}12.0 \\
11 \\
13 \\
11 \\
11 \\
11 \\
13 \\
27\end{array}$ & $\begin{array}{l}10.0 \\
10 \\
11.5 \\
9 \\
10 \\
10 \\
12 \\
25\end{array}$ & $\begin{array}{l}0,117 \\
0.129 \\
0.108 \\
0.143 \\
0.134 \\
0.139 \\
0.14 \\
0.24\end{array}$ & $\begin{array}{l}0,121 \\
0.14 \\
0.109 \\
0.144 \\
0.132 \\
0.145 \\
0.137 \\
0.126\end{array}$ & $\begin{array}{l}0,281 \\
0.798 \\
0.833 \\
0.965 \\
0.809 \\
0.859 \\
0.812 \\
0.397\end{array}$ & $\begin{array}{l}1523 \\
1422 \\
1402 \\
1574 \\
1478 \\
1533 \\
1823 \\
6718\end{array}$ & $\begin{array}{l}1571 \\
1539 \\
1421 \\
1587 \\
1453 \\
1600 \\
1775 \\
3392\end{array}$ & $\begin{array}{l}6174 \\
7984 \\
9574 \\
8682 \\
8086 \\
8594 \\
9744 \\
9936\end{array}$ \\
\hline $\begin{array}{l}\text { RXJ1028.6- } \\
0844\end{array}$ & $\begin{array}{l}0093160101 \\
0153290101\end{array}$ & $\begin{array}{l}2001-11-23 \\
2003-06-13 \\
\end{array}$ & $\begin{array}{l}7.0 \\
43.0\end{array}$ & $\begin{array}{l}7.0 \\
43.0\end{array}$ & $\begin{array}{l}4.0 \\
41.0\end{array}$ & $\begin{array}{l}0,1 \\
0,08\end{array}$ & $\begin{array}{l}0,114 \\
0,108\end{array}$ & $\begin{array}{l}0,348 \\
0,209\end{array}$ & $\begin{array}{l}802 \\
3728 \\
\end{array}$ & $\begin{array}{l}908 \\
4741\end{array}$ & $\begin{array}{l}3749 \\
17314\end{array}$ \\
\hline PKS2000-330 & 0104860601 & 2002-04-14 & 22.0 & 22.0 & 21.0 & 0,065 & 0,046 & 0,094 & 1492 & 1061 & 4034 \\
\hline PKS0237-23 & 0300630301 & 2006-01-19 & 26.0 & 26.0 & 25.0 & 0,255 & 0,36 & 0,913 & 6884 & 9714 & 45564 \\
\hline $4 \mathrm{C} 06.41$ & 0151390101 & 2003-05-18 & 59.0 & 59.0 & 58.0 & 0,199 & 0,206 & 0,623 & 11923 & 12358 & 72842 \\
\hline $3 C 432$ & 0406540101 & 2006-04-29 & 13.0 & 13.0 & 11.0 & 0,018 & 0,018 & 0,065 & 231 & 238 & 1506- \\
\hline $3 C 454$ & 0306370201 & $2005-05-25$ & 20.0 & 20.0 & 19.0 & 0,024 & 0,024 & 0,083 & 485 & 508 & 3138 \\
\hline PKS2351-154 & 0203240201 & 2004-12-04 & 67.0 & 67.0 & 64.0 & 0,0962 & 0,099 & 0,315 & 6544 & 6752 & 40904 \\
\hline
\end{tabular}


For six of these sources the enough amounts of data were also found in the public archive of the Swift/XRT observations; these data were not published before except only the part of the PKS 2149-306 observations which were being performed during December 2005, worked out by Bianchin et al. [1]. Swift/XRT Observation IDs, date of observations, total source counts and count rates in the extraction regions can be found in Table 2.

Table 2. Swift/XRT observation LOGs of the quasars sample

\begin{tabular}{|c|c|c|c|c|c|}
\hline Object name & SCW number & Obs. Date (first/last) & Exposure time, ks & Count rate (cts) & Total counts \\
\hline PKS0537-286 & 13 & 2005-11-23/2010-03-16 & 65 & 4.306 & 3053 \\
\hline PKS2149-306 & 12 & 2007-08-06/2011-05-13 & 29.9 & 5.05 & 3577 \\
\hline $4 \mathrm{C} 06.41$ & 7 & 2007-06-23/2011-02-16 & 17.5 & 0.87 & 614 \\
\hline PKS1406-076 & 39 & $2005-09-04 / 2011-05-20$ & 78.6 & 0.97 & 1108 \\
\hline PKS2126-158 & 6 & $2007-04-06 / 2010-05-03$ & 40.9 & 8.68 & 6152 \\
\hline PKS1830-211 & 15 & 2010-09-29/2011-04-05 & 33.2 & 2.41 & 1707 \\
\hline
\end{tabular}

EPIC date for all the objects were processed with XMM-Newton Standard Analysis System (SAS, public release version 11.0.0).

SAS software and its description can be found at http://xmm.vilspa.esa.es/sas/. The effective exposure times for both MOS and PN cameras after filtering of bad-flagged data are shown in the Table 1. To obtain the source lightcurves, we extracted full count rates from empty circles areas with different radii near the sources, on the same CCD plates. The background counts were subtracted (with corresponding factors taking into account different background areas) from the total counts from the source regions to obtain the cleaned lightcurves. The individual background-subtracted lightcurves do not show the fast intraday variability during the XMM-Newton observations.

EPIC spectra were obtained through standard SAS procedures: evselect, arfgen, and rmfgen. For spectra filtering, the single high-energy events were extracted in order to identify soft proton flares ( $E>10 \mathrm{keV}$, for pattern zero only; the time-bin sizes were $100 \mathrm{~s}$ for the pn and $10 \mathrm{~s}$ for the MOS). Good time intervals were defined using standard SAS procedure tabgtigen (with rate parameter $1.0 \mathrm{cts} / \mathrm{s}$ for the pn camera and $0.35 \mathrm{cts} / \mathrm{s}$ for the MOS) and then the event files have been corrected. In the case of the lightcurves we have not used tabgtigen, but simply have subtracted the background counts from the total ones in order to obtain a continuous time row.

Obtained MOS1 and MOS2 spectra for each observation were merged with each other using the addspec procedure, as well as the spectra obtained by the same device during the different observations of the same object were merged together to obtain the total-time spectrum for this object.

All the Swift/XRT observations were processed in photon counting mode (we choose only these in which there was greater than 1000 counts). Swift/XRT data were reduced through HEASOFT, version 6.14 (using xrtpipeline and procedures xselect and xrtmkarf). And again, the background counts from empty regions were subtracted from the total counts from the 45 arcsec-radii circular regions around the source to obtain its cleaned spectra.

Modeling the spectra. The data analysis was performed using HEASOFT 6.14 , XSPEC v.12 package (http://heasarc.nasa.gov/lheasoft/). To all the objects the model, including the direct and reflected power-law parts with exponential cut-off, absorbed both in the host galaxy and in the Galaxy, was applied. For the major part of the objects of the sample the XSPEC model used was:

pexrav*zphabs* ${ }^{*}$ habs.

Both direct and reflected parts of the inner machine emission are described by pexrav by Magdziarz \& Zdziarsky [19]; two other components describe the neutral absorption in the host AGN (zphabs) and in the Galaxy (phabs). The Galactic column densities of the absorbing media were frozen to the values found by Dickey \& Lockmann [7], except only 3C 454 for which the corresponding value appears to be too high. For this object the model was used in the form

pexrav*phabs,

and column density of the absorbing material in the Galaxy was not frozen.

For the gravitational lens system PKS1830-21 the broken power-law was used instead of the simple power-law, thus the model is:

bexrav*zphabs*phabs,

bexrav [19] have two additional fitting parameters comparably to pexrav model: additional photon index $\Gamma_{2}$ and the break energy (photon index $\Gamma_{1}$ is used below the break energy $E_{b}$, and $\Gamma_{2}$ is used above it. Finally, for PKS2126-158 the ionized absorber model was applied to describe the proper absorption in the host AGN:

pexrav*absori*phabs

following [21].

For the significant part of the quasars of the sample models with exponential cut-off at high energies and reflection appeared to be significantly better than simple power-law model widely used before. For instance, the null-hypothesis (i.e. simple power-law vs. reflected one with cut-off at high energies) probabilities are $17 \%$ for PKS 1406-076, $14 \%$ for 3C 454, 1 \% for PKS 2126-158, 0.8 \% for 3C 432, $0.7 \%$ for PKS0237-23, and 0.1\% for PKS2149-306, PKS2351-154 and PMN525-3343. For all the others the differences between these two models are statistically insignificant.

All the parameters of the spectral fits are shown in the Table 2.

Discussion. The result on PKS 0537-286, as well as the reflected model for PKS1406-076 gives significantly better fit than PL one, obtained in [12]. The photon indices and the break energy obtained here for the gravitationally lensed quasar PKS 1830-211 are similar to those published in [12]; identical photon index was obtained by De Rosa et al. from the Chandra and INTEGRAL observations of this object [6].

For the three quasars the XMM-Newton data were processed for the first time (Q0952 + 179, 3C 432, 3C 454), as well as the Swift/XRt data for $4 \mathrm{C}$.

The average parameters on the sample are: $\Gamma=1.59 \pm 0.04$, high-energy cut-off $E_{C}=77 \mathrm{keV}$, reflection parameter $\mathrm{R}=3.2$ and column density of the absorbing material $\mathrm{N}_{\mathrm{H}}=4.2 * 10^{21} \mathrm{~cm}^{-2}$. The mean value of the absorption, as well as all the individual values of it, are on the level typical for type 1 AGNs. For one object of the set, i.e. PK1830-211, proper column 
density cannot be determined due to the presence on the line of the sight of the intervening galaxy playing the role of a gravitational lens. Also, for 3C 454 the value of Galactic absorption is not compatible with the XMM/EPIC spectrum; thus only the Galactic absorption was considered for this object, and the upper limitation on can be found in the Table 3.

Table 3. Individual fits to the quasars spectra

\begin{tabular}{|c|c|c|c|c|c|c|c|c|c|c|}
\hline 0 & 1 & 2 & 3 & 4 & 5 & 6 & 7 & 8 & 9 & 10 \\
\hline Q0952+179 & 1.472 & 2.67 & XMM/EPIC & $1.59 \pm 0.03$ & - & - & $0.24 \pm 0.04$ & $213.3 / 200$ & $52_{-13}^{+24}$ & $<0.3$ \\
\hline \multirow{4}{*}{ PKS0537-286 } & \multirow{4}{*}{3.104} & \multirow{4}{*}{2.1} & XMM/EPIC1 & $1.25 \pm 0.01$ & - & - & $0.06 \pm 0.04$ & $1570.6 / 913$ & $50_{-8}^{+10}$ & $0.43 \pm 0.05$ \\
\hline & & & XMM/EPIC2 & $1.08 \pm 0.01$ & - & & $0.15 \pm 0.05$ & $989.3 / 892$ & $34 \pm 2$ & $0.57 \pm 0.08$ \\
\hline & & & Swift/XRT & $1.24 \pm 0.05$ & - & - & $1.0 \pm 0.5$ & $94.8 / 98$ & $90_{-30}^{+70}$ & $0.25 \pm 0.20$ \\
\hline & & & total & $1.15 \pm 0.08$ & - & - & $0.47 \pm 0.03$ & $1492.5 / 1012$ & $35 \pm 1$ & $0.64 \pm 0.05$ \\
\hline \multirow{3}{*}{ PKS1406-076 } & \multirow{3}{*}{1.494} & \multirow{3}{*}{2.77} & XMM/EPIC & $2.08 \pm 0.06$ & - & - & $0.14 \pm 0.05$ & $64.4 / 55$ & $>95$ & $>3.3$ \\
\hline & & & Swift/XRT & $1.78 \pm 0.15$ & - & - & $<0.26$ & $13.1 / 10$ & $>10$ & $>5.7$ \\
\hline & & & total & $2.0 \pm 0.07$ & - & - & $0.14 \pm 0.07$ & $78.0 / 69$ & $>53$ & $>4.7$ \\
\hline \multirow{5}{*}{ PKS $1830-211$} & \multirow{5}{*}{$\begin{array}{c}2.5 \\
\text { (qua- } \\
\text { sar), } \\
0.886 \\
\text { (lens) }\end{array}$} & \multirow{5}{*}{20.5} & XMM/EPIC1 & $0.93 \pm 0.03$ & $2.9 \pm 1.4$ & $3.8 \pm 0.3$ & $2.6 \pm 0.2$ & $253.7 / 248$ & $3.5_{-0.6}^{+0.4}$ & $<0.08$ \\
\hline & & & XMM/EPIC2 & $0.81 \pm 0.01$ & $2.8 \pm 1.9$ & $3.7 \pm 0.2$ & $2.1 \pm 0.1$ & $471.7 / 442$ & $43 \pm 2$ & $<0.09$ \\
\hline & & & XMM/EPIC3 & $0.85 \pm 0.02$ & $2.0 \pm 0.7$ & $3.5 \pm 0.1$ & $1.81 \pm 0.08$ & $1060.9 / 1019$ & $42 \pm 3$ & $<0.09$ \\
\hline & & & Swift/XRT & $1.19 \pm 0.05$ & $2.9 \pm 2$ & $3.5_{-0.6}^{+0.4}$ & $2.8 \pm 0.2$ & $79.8 / 84$ & $49_{-6}^{+9}$ & $1.05 \pm 0.23$ \\
\hline & & & total & $0.81 \pm 0.01$ & $3 \pm 1$ & $3.7_{-0.3}^{+0.1}$ & $1.98 \pm 0.06$ & $480.3 / 464$ & $42 \pm 2$ & $<0.02$ \\
\hline \multirow{3}{*}{ PKS 2126-158 } & \multirow{3}{*}{3.26} & \multirow{3}{*}{4.75} & XMM/EPIC & $1.26 \pm 0.01$ & - & $31 \pm 4$ & $3.1 \pm 0.2$ & $1770.6 / 1479$ & $38 \pm 1$ & $0.28 \pm 0.04$ \\
\hline & & & Swift/XRT & $1.32 \pm 0.03$ & - & $31_{-18}^{+28}$ & $3.3 \pm 0.4$ & $778.3 / 886$ & $31 \pm 3$ & $<0.6$ \\
\hline & & & total & $1.26 \pm 0.01$ & - & $31 \pm 4$ & $3.1 \pm 0.2$ & $1770.6 / 1479$ & $38 \pm 1$ & $0.28 \pm 0.04$ \\
\hline \multirow{3}{*}{ PKS 2149-306 } & \multirow{3}{*}{2.345} & \multirow{3}{*}{2.1} & XMM/EPIC & $1.36 \pm 0.01$ & - & - & $<0.06$ & $1634.7 / 1363$ & $33 \pm 1$ & $0.56 \pm 0.06$ \\
\hline & & & Swift/XRT & $1.19 \pm 0.03$ & - & - & $<0.8$ & $767.6 / 774$ & $21 \pm 2$ & $0.8 \pm 0.2$ \\
\hline & & & total & $1.34 \pm 0.01$ & - & - & $<0.07$ & $2402.3 / 2142$ & $33 \pm 1$ & $0.58 \pm 0.05$ \\
\hline \multirow{9}{*}{$\begin{array}{l}\text { PMN0525- } \\
3343\end{array}$} & \multirow{9}{*}{4.413} & \multirow{9}{*}{2.2} & XMM/EPIC1 & $1.41 \pm 0.04$ & - & - & $0.5 \pm 0.3$ & $158.9 / 153$ & $44_{-7}^{+9}$ & $<0.15$ \\
\hline & & & XMM/EPIC2 & $1.49 \pm 0.02$ & - & - & $0.76 \pm 0.14$ & $412.4 / 376$ & $79_{-11}^{+14}$ & $<0.16$ \\
\hline & & & XMM/EPIC3 & $1.48 \pm 0.03$ & - & - & $0.8 \pm 0.2$ & $273.2 / 222$ & $65_{-10}^{+13}$ & $<0.23$ \\
\hline & & & XMM/EPIC4 & $1.55 \pm 0.03$ & - & - & $1.0 \pm 0.2$ & $198.7 / 221$ & $87_{-16}^{+25}$ & $0.15 \pm 0.13$ \\
\hline & & & XMM/EPIC5 & $1.42 \pm 0.03$ & - & - & $0.7 \pm 0.2$ & $179.3 / 194$ & $36 \pm 4$ & $0.15 \pm 0.13$ \\
\hline & & & XMM/EPIC6 & $1.55 \pm 0.05$ & - & - & $3_{-2}^{+3}$ & $170.3 / 149$ & $51_{-8}^{+11}$ & $0.6 \pm 0.2$ \\
\hline & & & XMM/EPIC7 & $1.5 \pm 0.05$ & - & - & $0.5 \pm 0.4$ & $94.5 / 87$ & $37_{-6}^{+7}$ & $0.8 \pm 0.3$ \\
\hline & & & XMM/EPIC8 & $1.35 \pm 0.03$ & - & - & $0.7 \pm 0.2$ & $201.4 / 176$ & $36 \pm 4$ & $0.3 \pm 0.2$ \\
\hline & & & total & $1.49 \pm 0.01$ & - & - & $0.7 \pm 0.1$ & $464.9 / 405$ & $38_{-5}^{+6}$ & $<0.17$ \\
\hline \multirow{3}{*}{$\begin{array}{l}\text { RXJ1028.6- } \\
0844\end{array}$} & \multirow{3}{*}{4.276} & \multirow{3}{*}{4.59} & XMM/EPIC1 & $0.91 \pm 0.05$ & - & - & $<0.4$ & $73.7 / 57$ & $38_{-5}^{+6}$ & $<1.1$ \\
\hline & & & XMM/EPIC2 & $1.31 \pm 0.03$ & - & - & $0.8 \pm 0.2$ & $200.2 / 150$ & $53_{-5}^{+6}$ & $0.22 \pm 0.11$ \\
\hline & & & total & $1.28 \pm 0.02$ & - & - & $0.6 \pm 0.2$ & $183.5 / 143$ & $97_{-16}^{+24}$ & $<0.4$ \\
\hline PKS0237-23 & 2.22 & 2.23 & XMM/EPIC & $1.62 \pm 0.02$ & - & - & $0.04 \pm 0.02$ & $803.9 / 763$ & $24_{-1}^{+2}$ & $1.2 \pm 0.2$ \\
\hline PKS2000-330 & 3.77 & 7.89 & XMM/EPIC & $1.68 \pm 0.03$ & - & - & $<0.4$ & $218.9 / 208$ & $213_{-90}^{+483}$ & $<0.12$ \\
\hline \multirow{3}{*}{ 4C 06.41} & \multirow{3}{*}{1.27} & \multirow{3}{*}{5.8} & XMM/EPIC & $2.02 \pm 0.01$ & - & - & $<0.9$ & $1289.3 / 1054$ & $21 \pm 1$ & $11 \pm 4$ \\
\hline & & & Swift/XRT & $1.9 \pm 0.1$ & - & - & $0.2 \pm 0.1$ & $229.2 / 330$ & $89_{-27}^{+87}$ & $<3$ \\
\hline & & & total & $2.02 \pm 0.01$ & - & - & $<0.8$ & $1297.6 / 1062$ & $21 \pm 1$ & $11 \pm 2$ \\
\hline $3 C 432$ & $\begin{array}{c}1.78 \\
5 \\
\end{array}$ & 8.1 & XMM/EPIC & $2.72 \pm 0.11$ & - & - & $0.2 \pm 0.1$ & $56.7 / 65$ & $>53$ & $18 \pm 6$ \\
\hline 3C454 & $\begin{array}{c}1.75 \\
7 \\
\end{array}$ & 82.5 & XMM/EPIC & $1.33 \pm 0.13$ & - & - & $<0.81$ & $26.8 / 20$ & $22_{-8}^{+20}$ & $<1$ \\
\hline PKS2351-154 & 2.67 & 10.33 & XMM/EPIC & $1.9 \pm 0.03$ & - & - & $<0.8$ & $556.8 / 500$ & $50_{-6}^{+8}$ & $1.8 \pm 0.2$ \\
\hline
\end{tabular}

0 - Object name;

1 - Redshift z;

2 - Hydrogen column density in the Galaxy, $\mathrm{N}_{\mathrm{HO}}$, in $10^{20} \mathrm{~cm}^{-2}$, following [7];

3 - Data;

4 - photon indices $\Gamma_{1}$ (for PKS $1830-211$ ) or $\Gamma$ (for all the others);

5 - photon index $\Gamma_{2}$ (for PKS $1830-211$ );

6 - ionization level $\chi$ in keV (for PKS 2126-158) or break energy $E_{b}$ in keV(for PKS $1830-211$ );

7 - Proper hydrogen column density of the absorbing material, or column density of the absorbing material in the galactic-lens (for PKS $1830-211$ ), or in the Galaxy (for $3 \mathrm{C} 454$ ), in $10^{22} \mathrm{~cm}^{-2 ;}$

8 - the discrepancy $\chi^{2}$ div. degrees-of-freedom;

9 - high-energy cut-off $\mathrm{E}_{\mathrm{c}}, \mathrm{keV}$;

10 - reflection parameter $R$. 
Both the photon index and reflection parameter are changing over the sample in wide ranges, and for the latter it should be noticed that the values significantly overwhelming 1 obtained for $4 \mathrm{C} 06.41$ and $3 \mathrm{C} 432$ can be considered as the sign of more complex geometry than the lamp post one use in pexrav model.

The mean value of the exponential cut-off at high energies over the set, as well as the most part of the individual cut-off values are essentially or at least partially below $100 \mathrm{keV}$, and thus in a good agreement with the predictions of the "spinpardigm" model of AGN central machine for RL AGNs[2]. The only exception is PKS2000-330, for which the cut-off value is significantly higher, and this object can be recommended for further more detailed investigations.

Conclusions. The X-ray data of XMM-Newton and Swift/XRT observations of the sample of radio-loud quasars with the redshifts $z>1$ from the cross-correlation of PKS radio catalog and Veron-Veron AGN catalog were analyzed to compare their spectral parameters with the consequences of the "spin-paradigm" model of the AGN "central engine". The model the reflected and absorbed power-law spectrum with an exponential cut-off at high energies was applied to fit the main part of the spectra of these quasars in the energy range $0.3-10 \mathrm{keB}$, giving the following average values of the spectral parameters over the set: photon index $\Gamma=1.59 \pm 0.04$, high-energy cut-off $E_{C}=77 \mathrm{keV}$, reflection parameter $\mathrm{R}=3.2$ and column density of the absorbing material $\mathrm{N}_{\mathrm{H}}=4.2 * 10^{21} \mathrm{~cm}^{-2}$. The value of the exponential cut-off at high energies for the whole set, as well as the individual values of it for the objects of the set, are in good agreement with the "spin-paradigm" predictions, being essentially smaller then $100 \mathrm{keV}$. The only exception is except PKS2000-330, with cut-off value $213_{-90}^{+483} \mathrm{keV}$.

\section{Literature}

1. The changing look of PKS 2149-306/ V. Bianchin, L. Foschini, G. Ghisellin, G. Tagliaferri et. at. // Astron. \& Astroph., 2009. - Vol. 496, No 2. - P. 423-428.

2. PKS 0537-286, carrying the information of the environment of SMBHs in the early universe / E. Bottacini, M. Ajello, J. Greiner et al. // Astronomy \& Astrophysics, 2010. - Vol. 509. - P. 1-8

3. ROSAT spectra of quasars / P. Buehler, T. J.-L. Courvoisier, R. Staubert, H. Brunner, G. Lamer // Astron. \& Astroph., 2010. - Vol. 295, № 2. - P. 309-316.

4. Chartas G. X-Ray Observations of Gravitationally Lensed Quasars: Evidence for a Hidden Quasar Population / G. Chartas // Astroph. J., 2000. - Vol. 531,

No 1. - P. 81

5. Variable X-ray absorption toward the gravitationally-lensed blazar PKS 1830-211 / X. Dai, S.Mathur, G. Chartas, S. Nair et al. // Astron. J., 2008. - Vol.135, No 1. - P. 333-337.

6. The broad-band X-ray spectrum of the blazar PKS B1830-211 by Chandra and INTEGRAL / A. de Rosa, Piro L., A. Tramacere, E. Massaro et al. // Astron. \& Astroph., 2005. - Vol. 438, Is. 1. - P. 121-126.

7. Dickey J.M. H I in the Galaxy / J.M. Dickey, F.J. Lockman // A\&A, 1990. - Vol. 28. - P. 215-261.

8. The remarkable gamma-ray activity in the gravitationally lensed blazar PKS 1830-211 / I. Donnarumma, A. de Rosa, V. Vittorini, H.R. Miller et al. // Astron.

J. Lett., 2011. - Vol. 736. - Iss. 2 - P. L 30.

9. 150 keV Emission from PKS 2149-306 with BeppoSAX / M. Elvis, F. Fiore, A. Siemiginowska et al. // Astroph.J., Vol. 543, No 2. - P. 545.

10. Absorption in X-ray spectra of high-redshift quasars / M. Elvis, F. Fiore, B. Wilkes et al. // Astroph. J., 1994. - Part 1. - Vol. 422, No 1. - P. 60-72.

11. Chandra Observations of Two High-Redshift Quasars / T. Fang, H. L. Marshall, G. L. Bryan, C. R. Canizares // Astroph. J., 2001. - Vol. 555, Iss. 1. - P. 356-363.

12. Ferrero E. XMM-Newton observations of four high-z quasars / E. Ferrero, W. Brinkmann // Astron. \& Astrophys., 2003. - Vol. 402. - P. 465-476.

13. XMM-Newton observations of a sample of $\gamma$-ray loud active galactic nuclei / L. Foschini, G. Ghisellini, C.M. Raiteri et al. // Astron. \& Astrophys., 2006. - Vol. 453. - P. 829 .

14. Garofalo D. Retrograde versus Prograde Models of Accreting Black Holes / D. Garofalo // Advances in Astronomy, 2013. - Id. 213105.

15. Chasing the heaviest black holes of jetted Active Galactic Nuclei / G. Ghisselini, R. Della Ceca, M. Volonteri et al. // MNRAS, 2010. - Vol. 405. - P. 387.

16. XMM-Newton Observations of Two High-Redshift Quasars: RX J1028-0844 and BR 0351-1034 / D. Grupe, S. Mathur, B. Wilkes, M. Elvis // Astron. J., 2004. - Vol. 127. Iss. 1. - P. 1-9

17. XMM-Newton Observations of High Redshift Quasars / D. Grupe, S.Mathur, B. Wilkes, P. Osmer // Astron.J., 2006. - Vol. 131. - P. 55-69.

18. Radio loud active galaxies in the northern ROSAT all-sky survey. III New spectroscopic identifications from the Rass-Green bank BL Lacertae survey

/ S. Laurent-Mühleisen, R. Kollgaard, R. Giardullo et al. // Astron. J., Supp. Series, 1998. - Vol. 118. - P. 127-175.

19. Magdziarz P. Angle-dependent compton reflection of X-rays and gamma-rays / P. Magdziarz, A.A. Zdziarski // MNRAS, 1995. - Vol. 273, Iss. 3. - P. $837-848$.

20. Mathur S. X-Ray Absorption toward the Einstein Ring Source PKS 1830-211 / S. Mathur, S. Nair // Astroph. J., 1997. - Vol. 484, N 1. - P. 140.

21. XMM-Newton spectroscopy of high-redshift QSOs / K.L. Page, J.N. Reeves, P.T. O'Brien, M.J.L. Turner // MNRAS. - 2005. - Vol.364. - P. $195-207$.

22. Reeves J.N. X-ray Spectra of a large sample of Quasars with ASCA / J.N. Reeves, M.J.L. Turner // MNRAS, 2000. - Vol. 316. - P. 234.

23. The first XMM-Newton spectrum of a high redshift quasar - PKS 0537-286 / J.N. Reeves, M.J.L. Turner, P.J. Bennie et al. // Astron. \& Astroph., 2001. - Vol. 365. - P. L116-L121.

24. The complex X-ray spectra of two high redshift quasars observed with ASCA / P. Serlemitsos, T. Yaqoob, G. Ricker et. al. // PASJ, 1994. - Vol. 46, No 3. -P. L43-L47.

25. ASCA observations of high redshift quasars / J. Siebert, M. Matsuoka, W. Brinkmannet al. // Astron. \& Astroph., 1996. - Vol. 307. - P. 8.

26. A Highly Doppler Blueshifted Fe-K Emission Line in the High-Redshift QSO PKS 2149-306 / T. Yaqoob, I.M. George, K. Nandra et al. // Astroph. J., 1999. - Vol. 525. - P. L9-L12.

27. XMM obsenvations of the high-redshift quasar RXJ1028.6 - 0844 at $z=4.276$ : soft X-ray spectral flattening / W. Yuan, A.C. Fabian, A. Celotti et al. // MNRAS, 2005. - Vol. 358. - Iss. 2. - P. 432-440.

28. Identification of a complete sample of northern ROSAT All-Sky Survey X-ray sources. V. Discovery of a $z=4.28$ QSO near the RASS source RX J1028.6-0844 / F.-J. Zickgraf, W. Voges, J. Krautter et al. // Astron. \& Astroph., 1997. - Vol. 323. - P. L21-L24.

Надійшла до редколегії 08.10.13

О. Федорова, канд. фіз.-мат. наук,

КнУ имені Тараса Шевченка, Київ

\section{РЕНТГЕНІВСЬКІ ВЛАСТИВОСТІ ВІДДАЛЕНИХ РАДІОГУЧНИХ КВАЗАРІВ ЗА ДАНИМИ ХМM-NEWTON TA SWIFT/XRT}

Оброблено та промодельовано рентгенівські дані супутникових спостережень XMM-Newton ma Swift/XRT вибірки радіогучних квазарів з червоним зміщенням z>1 за крос-кореляцією радіокаталогу PKS та каталогу АЯГ Верона і Верон. Для підгонки спектрів е діапазоні енергій 0.3-10 кеВ використано модель степеневого континууму з відбиттям та поглинанням, 3 експоненційним завалом на високих енергіях до всіх квазарів вибірки, окрім гравітаційно-лінзової системи PKS1830-211, до якої було застосовано модель із двома

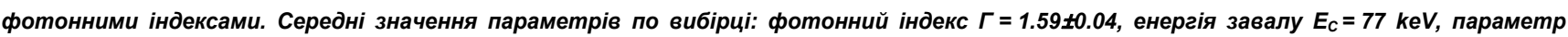
відбиття $R=3.2$, стовпчикова густина поглинаючої матерії $N_{H}=4.2^{\star} 10^{21} \mathrm{~cm}^{-2}$. Усі об'єкти вибірки, за виключенням РКS2000-330, демонструють експоненційний завал на енергіях нижче 100 кеВ зәідно з передбаченнями спін-парадигми для радиогучних АЯГ.

Ключові слова: АЯГ, квазари, рентгенівські спостереження. 
Е. Федорова, канд. физ.-мат. наук,

КнУ имени Тараса Шевченко, Киев

\section{РЕНТГЕНОВСКИЕ СВОЙСТВА УДАЛЕННЫХ РАДИОГРОМКИХ КВАЗАРОВ}

ПО ДАННЫМ XMM-NEWTON И SWIFT/XRT

Обработаны и промоделированы рентгеновские данные спутниковых наблюдений XMM-Newton u Swift/XRT выборки радиогромких квазаров с красным смещением z>1 по кросс-корреляции радиокаталога PKS и каталога АЯГ Верона и Верон. Для подгонки спектров в диапазоне энергий 0.3-10 кеВ использовалась модель степенного континуума с отражением и поглощением, с экспоненциальным завалом на высоких энергиях для всех квазаров выборки, кроме гравитационно-линзовой системы РКS1830-211, к которой была применена модель с двумя фотонными индексами. Средние значения параметров по выборке: фотонный индекс Г= 1.59£0.04, энераия завала $E_{C}=77 \mathrm{keV}$, параметр отражения $R=3.2$, плотность поглощающей материи на луче зрения $N_{H}=4.2 * 10^{21}$ см$^{-2}$. Bсе объекты выборки, за исключением PKS2000-330, демонстрируют экспоненциальный завал на энергиях ниже 100 кеВ, в согласии с выводами спин-парадигмы для радиогромких АЯГ.

Ключевые слова: АЯГ, квазары, рентгеновские наблюдения

Удк 524.7

Л. Задорожна, канд. фіз.-мат. наук, Б. Гнатик, д-р фіз.-мат. наук КНУ імені Тараса Шевченка, Київ

\section{КОСМОЛОГІЧНИЙ ШВИДКИЙ РАДІОСПАЛАХ "SPARК" ЯК НЕТЕПЛОВЕ ВИПРОМІНЮВАННЯ ВІД УДАРНОЇ ХВИЛІ НАВКОЛО НАДПРОВІДНОЇ СТРУНИ}

Надпровідні космічні струни можуть бути потужними джерелами нетеплового випромінювання. Випромінювання від ударної хвилі навколо прикаспової області має характер вузьконаправлених спалахів. Показано, що відкритий у 2007 р. на 64-метровому радіотелескопі Паркс мілісекундний позагалактичний швидкий радіоспалах FRB010724 "spark" неототожненої природи може бути пояснений як синхротронне випромінювання від ударної хвилі навколо прикаспової області надпровідної космічної струни енергетичного масштабу, близького до Великого Об'єднання. Тривалість, потік $і$ частота радіовипромінювання спостережуваного спалаху добре узгоджуються із запропонованою моделлю. Наразі виявлено ще п'ять швидких радіоспалахів з подібними характеристиками, що підкріплює пояснення цього явища як випромінювання від петель космічних струн.

Ключові слова: космічні струни, швидкий радіоспалах, нетеплове випромінювання, ударні хвилі.

1. Вступ. Мілісекундний радіоспалах було виявлено групою вчених на чолі з Лорімером у 2007 році [1] під час обробки архівних даних, отриманих при спостереженні Магелланових Хмар на частоті 1.4 ГГц 3 допомогою 64-метрового радіотелескопа Паркс в Австралії. Спалах було помічено в даних від 24 липня 2001 року за Всесвітнім координованим часом і він знаходився приблизно на три градуси південніше Малої Магеланової Хмари. Потік від радіоспалаху $F=30$ Ян, тривалість $T<5$ мс. Властивості спалаху не дозволяють асоціювати його 3 фрізичними явищами, що могли б відбутися в нашій Галактиці чи Малій Магелановій Хмарі. Сучасні моделі для вільних електронів космічної плазми дають можливість розрахувати, що спалах відбувся на відстані $r \leq 1$ Гпк, що відповідає червоному зміщенню $z \leq 0.3$. Дані за подальші 90-годинні спостереження показали, що такий радіоспалах являв собою одиничне явище, тобто особливу подію. У 2013 році з'явилося повідомлення про відкриття на радіотелескопі Паркс ще чотирьох радіоспалахів позагалактичної природи. Спостережуване явище отримало офіційну назву швидкий радіоспалах (анг. Fast radio burst). Ці чотири радіоспалахи - FRB110220, FRB110627, FRB110703, FRB120127, виявлені при обробці даних за 2011-2012 роки, мають характеристики, подібні до "спалаху Лорімера", якому був присвоєний номер FRB010724 (анг. "spark", "Lorimer burst"), для них червоне зміщення z лежить в межах від 0.45 до 0.81, потік варіюється від $F=0.4$ Ян до $F=1.3$ Ян, тривалість від $T=1.1 \mathrm{мc} \mathrm{до} T=5.6 \pm 0.1 \mathrm{mс} \mathrm{[2].}$ Нещодавно з допомогою радіотелескопу обсерваторії Аресібо виявленно ще один швидкий радіоспалах $\mathrm{FRB}$ 121102, що був задетектований при обробці 1,4 ГГц пульсарного ALFA огляду, у північній півкулі неба в регіоні Галактичного анти-центру. Тривалість спалаху $T=3 \pm 0.5$ мс, потік $F=40$ мЯн [3]. Міжнародна група вчених на чолі з Лаурою Спітлер із Радіоастрономічного інституту Макса Планка в Бонні, (Німеччина), що займалися обробкою даних по FRB121102, вважають, що в середньому щохвилини в небі відбувається сім швидких радіоспалахів [3]. Так як існує цілий набір швидких радіоспалахів із подібними характеристиками, це дозволяє зробити припущення про їх однакову природу. Пропонується кілька пояснень космологічних швидких радіоспалахів, такі як: вибух наднової, спалах від магнетару чи злиття релятивістських об'єктів - чорних дірок або нейтронних зір. Існує також пояснення для "спалаху Лорімера" FRB010724, запропоноване Вачаспаті у 2008 році [4]. Цей родіоспалах вдалося пояснити як електромагнітне випромінювання від самоперетину і анігіляції частини надпровідної космічної струни енергетичного масштабу Великого Об'єднання зі струмом $i=10^{5}$ ГеВ.

Космічні струни представляють собою один із типів топологічних дефектів, які могли утворюватися під час фразових переходів полів зі спонтанним порушенням симетрії у ранньому Всесвіті. Прикладом такого фазового переходу є фазовий перехід теорії Великого Об'єднання (ТВО) - відділення сильної взаємодії від електрослабкої, що відбувся за $10^{-35}$ с з моменту Великого вибуху. Космічні струни - квазіодномірні (з товщиною порядку $d \sim \eta^{-1} \sim 10^{-30} \mathrm{~cm}$, де $\eta$ - енергетичний масштаб фазового переходу, рівний у випадку ТВО $\eta=\eta_{\text {Тво }} \sim 10^{16}$ ГеВ) безконечні (в межах нашого космологічного горизонту) чи замкнуті в петлі масивні (маса (натяг) одиниці довжини $\mu \sim \eta^{2} \sim 10^{22}$ г/см для ТВО-струн ) структури, які можуть відігравати важливу роль як в космологічному аспекті, так і в різноманітних астрофрізичних проявах. На різних етапах еволюції Всесвіту петлі космічних струн можуть відповідати за формування структур; утворення згущень темної матерії; магнетогенезис; впливати на іонізаційну 